\section{Pengaruh Panjang dan Kemiringan Lereng terhadap Stabilitas Keseluruhan Sheet Pile di Tanah Lunak}

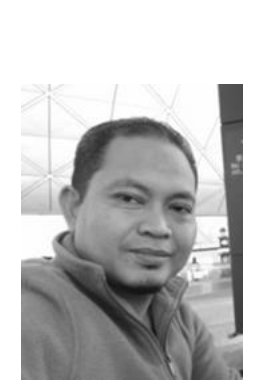

Penulis lahir di Banjarmasin pada 19 Juli 1975. Sarjana Teknik diselesaikan pada 1998 di Universitas Lambung Mangkurat. Men-dapatkan gelar S2 dan S3 pada tahun 2001 dan 2008 masing-masing dar ITS dan BUW Jerman. Sejak tahun 2001 sampai sekarang menjadi dosen di PS Teknik Sipil ULM bidang keahlian Geoteknik.y.arifin@ulm.ac.id

\section{Pendahuluan}

Dalam perencanaan dinding sheet pile, biasanya langkah-langkah perhitungannya adalah perhitungan tegangan aktif dan pasif tanah, diagram tegangan, penentuan panjang penetrasi sheet pile dan panjang total, perhitungan momen maksimum, dan perhitungan section modulus yang digunakan untuk penentuan tipe sheet pile yang digunakan (Das, 2007).

Langkah perencanaan sheet pile yang paling terakhir dan terpenting adalah perhitungan stabilitas keseluruhan. Kestabilan konstruksi diperiksa dengan menentukan faktor keamanan lereng. Dibanyak kasus, perhitungan ini tidak dilakukan akibatnya tidak diketahui faktor keamanan konstruksi setelah dilakukan timbunan. Apakah panjang sheet pile yang didapat mampu mencegah terjadinya keruntuhan di bawah konstruksi sheet pile.

Kondisi yang juga banyak diabaikan dalam perencanaan kostruksi sheet pile adalah kemiringan tanah di depan dinding. Untuk kondisi di sungai, tanah di depan dinding jarang dilakukan pengerukan seperti halnya yang dikerjakan untuk metode-metode backfilled dan dredged structure. Akibatnya perhitungan tegangan pasif dan stabilitas keseluruhan menjadi over estimate. Das (2007) menyarankan adanya pengurangan nilai koefisien tanah pasif pada tanah pasir tergantung dari kemiringan lereng dan sudut gesek dalam $(\phi)$ tanah. Khusus tanah lempung, Bowles (1996) menyarankan menggunakan program komputer untuk mendapatkan tekanan tanah pasif untuk kondisi seperti ini.

Dari kondisi-kondisi di atas, sangat jarang dibahas hubungan dari beberapa faktor tersebut terutama untuk kondisi tanah lunak sehingga paper ini membahas mengenai pengaruh panjang permukaan tanah dan kemiringan lereng di depan konstruksi sheet pile terhadap faktor keamanan stabilitas keseluruhan.
Kegagalan konstruksi sheet pile dapat disebabkan karena perencana kurang teliti dalam menganalisa stabilitas keseluruhan lereng. Kegalalan ini sering terjadi setelah timbunan di belakang sheet pile dilaksanakan. Paper ini fokus membahas mengenai pengaruh panjang dan kemiringan lereng terhadap stabilitas keseluruhan konstruksi sheet pile khususnya di tanah lunak. Metode finite element menggunakan program Plaxis 2D digunakan untuk menganalisa stabilitas kestabilan lereng yang ditunjukkan oleh nilai faktor keamanan. Model sheet pile dibuat dengan panjang terpancang $20 \mathrm{~m}$ dan tinggi timbunan $5 \mathrm{~m}$ yang ditimbung secara bertahap. Panjang lereng di depan konstruksi adalah 15, 30, dan $45 \mathrm{~m}$ atau setara dengan 1-3 kali panjang sheet pile yang tertanam. Kemiringan lereng yang diaplikasikan pada model adalah 0(datar), 5, 10, dan 15 derajat. Hasil analisa memperlihatkan besarnya pengaruh panjang dan kemiringan lereng di depan konstruksi dimana faktor keamanan berkurang 0,02 tiap kenaikan 1 derajat lereng.

www.bpi.ulm.ac.id

\section{Metode}

Analisa stabilitas sheet pile dilakukan dengan menggunakan program Plaxis 2D. Program ini telah digunakan oleh beberapa peneliti untuk menganalisa sheet pile tidak hanya permodelan komputer akan tetapi juga divalidasi dengan hasil pengamatan lapangan (Paikowsky dan Tan, 2005; Person dan Sigstroem, 2011; Wolters dkk, 2014).

Konstruksi dimodelkan berupa sheet pile dengan panjang total $20 \mathrm{~m}$, dimana $15 \mathrm{~m}$ dipancangkan ke dalam tanah dan $5 \mathrm{~m}$ berada dipermukaan. Timbunan dilakukan dalam 5 tahap dengan panjang total $5 \mathrm{~m}$ dimana masing-masing tahapan $1 \mathrm{~m}$.

Kemiringan lereng diambil terhadap horisontal dengan perubahan kemiringan tiap $5^{\circ}$. Maksimum kemiringan yang digunakan dalam penelitian ini adalah $15^{\circ}$, sehingga tahapan kemiringan yang digunakan adalah $0,5,10$, dan $15^{\circ}$.

Data tanah yang digunakan adalah data tanah lunak sedangkan sheet pile yang digunakan adalah sheet pile baja dengan data-data seperti terlihat pada Tabel 1 dan 2.

Untuk analisa panjang lereng di depan konstruksi sheet pile, analisa mempertimbangkan panjang sheet pile yang dipancangkan, sehingga panjang lereng yang diambil adalah 15,30 , dan $45 \mathrm{~m}$ atau setara dengan 1 , 2 , dan 3 kali panjang sheet pile.

\section{Hasil Analisa}

\section{Pengaruh Panjang Lereng di Depan Konstruksi Sheet pile}

Tiga model digunakan untuk menganalisa pengaruh panjang lereng yaitu 15, 30, dan $45 \mathrm{~m}$ atau setara dengan 1, 2, dan 3 kali panjang (3B) sheet pile. 
Tabel 1. Data tanah

\begin{tabular}{|c|c|c|c|c|c|}
\hline \multicolumn{2}{|c|}{$\begin{array}{l}\text { Mohr-Coulomb } \\
\text { Type }\end{array}$} & \multirow{2}{*}{$\begin{array}{c}\begin{array}{c}\text { Timbunan } \\
\text { undrained }\end{array} \\
16.00\end{array}$} & \multirow{2}{*}{$\begin{array}{c}\text { Tanah Asli I } \\
\text { undrained }\end{array}$} & \multirow{2}{*}{$\begin{array}{c}\text { Tanah Asli } 2 \\
\text { undrained }\end{array}$} & \multirow{2}{*}{$\begin{array}{c}\begin{array}{c}\text { Badan jalan } \\
\text { Undrained }\end{array} \\
18.00\end{array}$} \\
\hline$\gamma_{\text {unsat }}$ & {$\left[\mathrm{kN} / \mathrm{m}^{3}\right]$} & & & & \\
\hline$\gamma_{\text {sat }}$ & {$\left[\mathrm{kN} / \mathrm{m}^{3}\right]$} & 18.00 & 16.70 & 19.00 & 19.00 \\
\hline $\mathrm{k}_{\mathrm{x}}$ & [m/day] & 0.000 & 0.000 & 0.000 & 0.000 \\
\hline $\mathrm{k}_{\mathrm{y}}$ & {$[\mathrm{m} /$ day $]$} & 0.000 & 0.000 & 0.000 & 0.000 \\
\hline$e_{\text {init }}$ & {$[-]$} & 0.500 & 0.500 & 0.500 & 0.500 \\
\hline$c_{k}$ & {$[-]$} & $1 \mathrm{E} 15$ & $1 \mathrm{E} 15$ & $1 \mathrm{E} 15$ & 1E15 \\
\hline $\mathrm{E}_{\mathrm{ref}}$ & {$\left[\mathrm{kN} / \mathrm{m}^{2}\right]$} & 10000.000 & 2500.000 & 5000.000 & 10000.000 \\
\hline$v$ & {$[-]$} & 0.300 & 0.300 & 0.300 & 0.350 \\
\hline $\mathrm{G}_{\mathrm{ref}}$ & {$\left[\mathrm{kN} / \mathrm{m}^{2}\right]$} & 3846.154 & 961.538 & 1923.077 & 3703.704 \\
\hline$E_{\text {oed }}$ & {$\left[\mathrm{kN} / \mathrm{m}^{2}\right]$} & 13461.538 & 3365.385 & 6730.769 & 16049.383 \\
\hline$c_{\text {ref }}$ & {$\left[\mathrm{kN} / \mathrm{m}^{2}\right]$} & 0.50 & 11.80 & 10.00 & 50.00 \\
\hline$\varphi$ & {$\left[{ }^{\circ}\right]$} & 30.00 & 11.00 & 10.00 & 0.00 \\
\hline$\psi$ & {$\left[{ }^{\circ}\right]$} & 0.00 & 0.00 & 0.00 & 0.00 \\
\hline$E_{\text {inc }}$ & {$\left[\mathrm{kN} / \mathrm{m}^{2} / \mathrm{m}\right]$} & 0.00 & 0.00 & 0.00 & 0.00 \\
\hline $\mathrm{y}_{\mathrm{ref}}$ & {$[\mathrm{m}]$} & 0.000 & 0.000 & 0.000 & 0.000 \\
\hline$c_{\text {increment }}$ & {$\left[\mathrm{kN} / \mathrm{m}^{2} / \mathrm{m}\right]$} & 0.00 & 0.00 & 0.00 & 0.00 \\
\hline $\mathrm{T}_{\text {str. }}$ & {$\left[\mathrm{kN} / \mathrm{m}^{2}\right]$} & 0.00 & 0.00 & 0.00 & 0.00 \\
\hline $\mathrm{R}_{\text {inter. }}$ & {$[-]$} & 1.00 & 1.00 & 1.00 & 1.00 \\
\hline \multicolumn{2}{|c|}{ Interface permeability } & Netral & Netral & Netral & Netral \\
\hline
\end{tabular}

Tabel 2. Data Sheet Pile

\begin{tabular}{ccccccc}
\hline Parameter & $\begin{array}{c}\mathrm{EA} \\
{[\mathrm{kN} / \mathrm{m}]}\end{array}$ & $\begin{array}{c}\mathrm{EI} \\
{[\mathrm{kNm} / \mathrm{m}]}\end{array}$ & $\begin{array}{c}\mathrm{w} \\
{[\mathrm{kN} / \mathrm{m} / \mathrm{m}]}\end{array}$ & $\begin{array}{c}v \\
{[-]}\end{array}$ & $\begin{array}{c}\mathrm{Mp} \\
{[\mathrm{kNm} / \mathrm{m}]}\end{array}$ & $\begin{array}{c}\mathrm{Np} \\
{[\mathrm{kN} / \mathrm{m}]}\end{array}$ \\
\hline Turap & $9.7 \mathrm{E} 7$ & $2.08 \mathrm{E} 5$ & 3.40 & 0.35 & $1 \mathrm{E} 15$ & $1 \mathrm{E} 15$ \\
\hline
\end{tabular}

Stabilitas lereng dianalisa menggunakan faktor keamanan lereng. Masing-masing model dengan panjang lereng berbeda diplot terhadap faktor keamanan. Terlihat pada Gambar 1, faktor keamanan lereng berkurang dengan semakin panjangnya lereng. Semakin panjang lereng, garis keruntuhan yang terjadi semakin panjang. Hal ini memperlihatkan bahwa garis keruntuhan yang terjadi pada panjang lereng $15 \mathrm{~m}$ bukan garis keruntuhan yang menghasilkan faktor keamanan terkecil.

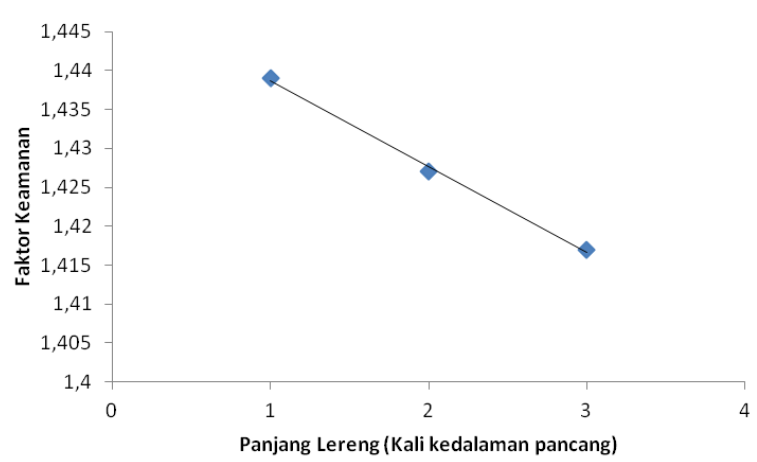

Gambar 1. Hubungan antara panjang lereng sebagai fungsi kelipatan panjang sheet pile dengan faktor keamanan
Pengaruh Kemiringan Lereng di Depan Konstruksi Sheet pile

Panjang lereng yang digunakan sama untuk semua kemiringan yaitu $45 \mathrm{~m}$. Empat kemiringan digunakan pada penelitian ini yaitu 0, 5, 10, dan15 derajat terhadap horisontal. Gambar 4(a) dan (b) memperlihatkan hasil analisa masing-masing untuk kemiringan lereng nol dan 15 derajat.

Hasil finite element dengan Plaxis didapatkan garis keruntuhan terjauh terletak antara $15-16 \mathrm{~m}$. Pada kondisi lain, garis keruntuhan terjauh mencapai 36-37 m. Hal ini memperlihatkan besarnya perubahan garis keruntuhan akibat perubahan kemiringan lereng di depan sheet pile. Perubahan besar juga terlihat pada faktor keamanan sheet pile.

Gambar 2 memperlihatkan pengaruh kemiringan lereng terhadap faktor keamanan sheet pile secara keseluruhan. Terlihat pada gambar, faktor keamanan berkurang dengan bertambahnya kemiringan lereng. Dan pada kemiringan $15^{\circ}$, faktor keamanan mendekati 1 . Artinya, untuk kasus dalam model ini, keringan lebih dari $15^{\circ}$ mengakibatkan keruntuhan terjadi pada sheet pile. Jika dianalisa penurunan faktor keamanan setiap kenaikan satu derajat adalah 0,02.

\section{Tekanan air pori di bawah timbunan}

Gambar 3 memperlihatkan nilai excess pore water pressure (tekanan air pori berlebih) di bawah timbunan pada konstruksi sheet pile. Terlihat pada gambar, excess pore water pressure tidak dipengaruhi oleh kemiringan dari lereng di depan sheet pile. Ini memperlihatkan bahwa berkurangnya 
faktor keamanan disebabkan oleh berkurangnya tegangan pasif tanah di depan sheet pile

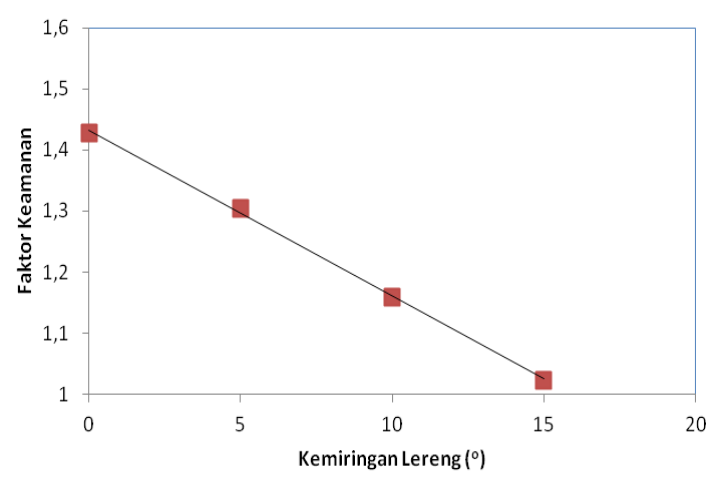

Gambar 2. Faktor keamanan sheet pile sebagai fungsi kemiringan lereng di depan sheet pile

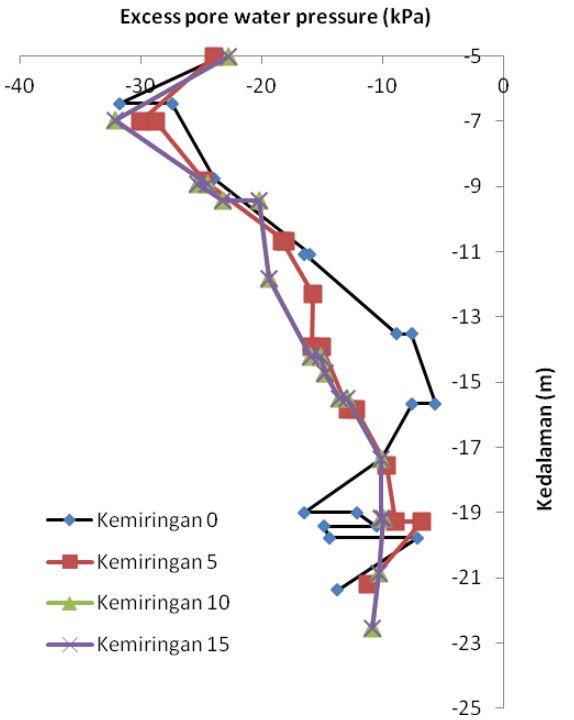

Gambar 3. Excess pore water pressure di bawah timbungan

\section{Kesimpulan}

Dari hasil perhitungan dan analisa disimpulkan dapat disimpulkan beberapa hal yaitu:

1. Semakin besar kemiringan lereng semakin kecil faktor keamanan lereng.

2. Untuk kasus yang diteliti, faktor keamanan lereng berkurang 0,02 setiap peningkatan 1 derajat kemiringan lereng.

3. Semakin panjang lereng semakin kecil faktor keamanan.

4. Semakin panjang sheet pile yang dipancangkan semakin panjang permukaan di depan sheet pile yang harus dianalisa.

5. Turunnya faktor keamanan disebabkan oleh berkurangnya tekanan pasif di depan turap.

\section{Ucapan Terimakasih}

Ucapan terimakasih kepada Program Studi Magister Teknik Sipil Universitas Lambung Mangkurat yang membiayai penelitian ini melalui DIPA ULM tahun 2014.

\section{Referensi}

Bowles J.E., Foundation analysis and design, Edisi ke5, The McGraw-Hill Companies, Inc., 1996.

Das B.M., Principles of Foundation Engineering, Thomson, Brooks, Cole, 2007.

Paikowsky S.G., Tan Y., Sheet pile wall design and performance in peat, Research Report, University of Massachusetts Lowell, 2005.

Person H., Sigstrom D, Staged excavation in soft clay supported by a cantilever sheet pile wall, Master Thesis, Chalmers University Of Technology, 2011.

Wolters H.J., Bakker K.J., de Gijt J.G., Reliability of Quay Walls Using Finite Element Analysis, Plaxis Bulletin, Spring issue (pp. 12-15), 2014 